\title{
Tax Collection in Northern Ghana during British Colonial Rule from 1898-1950 (Part Two)
}

\author{
Maasole S. Cliff \\ Department of Social, Political and Historical Studies \\ drmaasolegbaalu@gmail.com \\ DOI//http://dx.doi.org/10.4314/gjds.v16i1.9
}

\begin{abstract}
One aspect of administrative history that was bequeathed by British colonialism in Northern Ghana from 1898 to 1950 was that of tax collection. This came in two phases: the first commenced from 1898 to1930. This study is concerned with the second period that lasted from 1930 to 1950. Within this period the purpose or objective of the study argues that a clear tax policy was formulated for Northern Ghana which marked the reintroduction of direct taxation that was systematically imposed under a system of Native Administration based on the principles of indirect rule. Much archival material was obtained in the Public Records and Archival Administration Department both in Accra and Tamale. Oral interviews were carried out that engaged elderly people who hail from the North. Information was equally gathered from chiefs and educated elites who come from the area. Some of the latter are teachers in universities in Ghana. Secondary source material such as books and journals enhanced the study. Thorough preparations were made by the British regime towards the re-introduction of direct taxation culminating in its return. The study outlines the nature and method of collection, the expenditure that was entailed, and the social effects that direct taxation bestowed on the traditional social life of the inhabitants. The article concludes that tax collection in Northern Ghana was thus one of the most successful policies that was carried out by the British and that actual developments resulting in the provision of social infrastructure began with the reintroduction of direct taxation under the Native Administration system
\end{abstract}

Keywords: Native Administration, Customary Tribute, Nominal Rolls, Native Authorities, Metal Discs 


\section{INTRODUCTION}

Taxation has become a matter that is publicly determined with the individual citizen playing an important part as was demonstrated during and in the aftermath of both the American and French Revolutions of the eighteenth century (Ekeh, 1994). While Nsoh-Ambala (2008) considered taxation as the compulsory payment by individuals and companies to the state, Ali-Nakyea (2008) views it as the levying of compulsory contributions by public authorities having tax jurisdiction to defray the cost of their activities, and that no specific reward is gained by the taxpayer.

European Empires in Africa commonly adopted the principle of taxing the inhabitants of their colonies and protectorates as a means of raising revenue. The rationale was to make the colonies and the protectorates to pay their way because the policies governing the fiscal relations between the metropolitan power and their peripheral dependencies embodied a system of financial independence for the latter (Rotberg, 1967; Suret-Canale, 1971). In other words, the dependencies were to be governed in such a way that they do not constitute a financial burden on their colonial masters.

The taxation of Africans, as it was generally held, constituted the hub which Europeans colonialism could be hinged (Lugard, 1965). Taxation did not only provide the means by which social services could be provided, the assertion was that it would equally emphasise European rule or domination over the African. For instance, in the British Protectorate of the Northern Territories of the Gold Cost (now Northern Ghana), the first Chief Commissioner and Commandant, Lt. Col. Henry P. Northcott, was of the view that the early imposition of direct taxation on the people was a "convincing proof of paramountcy" of the British presence and as "the essence of easy rule over the natives". ${ }^{3}$ Not only were the Natives to be made to realise that they must contribute as far as their means allowed towards the finances of the Protectorate, they were to be acquainted with the principle of a constant direct taxation at the very inception of British rule.

This article gives taxation a detailed treatment within the context of administrative history during the period of British colonial rule in Northern Ghana. It focuses on the subject of taxation by considering the nature of taxation, the methods employed in collecting the taxes since these often constituted the key factors in the successful implementation of tax schemes, expenditure, and the effect of taxation on the traditional social life of the people.

3 Public Record and Archival Administration Department (PRAAD), Accra, Lt. Col .Henry P. Northcott, Report on the Administration of the Northern Territories of the Gold Coast for the year 1989-99, p.183. 
The article has been divided into two parts for the main reason that there were two phases to taxation in the area. The first phase was from1898 to1930. During this period, the British Administration pursued a haphazard and half-hearted policy on taxation. In these years, the British colonial régime could not take a firm decision or stand on what kind of taxes it would impose on the inhabitants in the area of present day Northern Ghana, until the 1930s. The issue of taxation during this period has been comprehensively dealt with in one study ${ }^{4}$.

This article begins from the 1930s when a clear tax policy was formulated for the area. This latter date marked the beginning of the second phase in which direct taxation was systematically imposed under a system of Native Administration based on the principles of indirect rule. The purpose or objective of this study is to demonstrate that the second period 1930 - 1950 saw the systematic imposition of a uniform tax which contrasted sharply with the ill-defined policy of the earlier phase. The dates 1898 and 1950 have also been chosen for the following reasons. The former marks the introduction of direct and indirect taxation in the area. Although the direct tax was abolished shortly afterwards as was the case in the first part of this article, it was re-introduced in the 1930s. In 1950, the existing tax system in the area became merged with Local Council rates after Local Councils were introduced as administrative institutions. The second part of the article will therefore deal with the efforts of the British regime to levy direct and indirect taxes on the people of Northern Ghana between 1930 and 1950.

The study relied much on archival material. This was obtained from the Public Records and Archival Administration Department located in Accra and Tamale. Opportunity afforded itself for the engagement of elderly people who hail from Northern Ghana in a series of oral interviews that proved helpful. Chiefs and the educated elite who hail from the area proffered useful information. Secondary source materials were of immense value.

\section{Preparations towards the Re-Introduction of Direct Taxation}

In 1928 the Acting Governor, Sir T. Shenton Thomas, revived the question of direct taxation in connection with the idea of building up a system of local Government on the principles of indirect rule. He gave the signal: "A system of taxation will be necessary" 5 . What the Governor had in mind was the establishment of a simple form of native administration by adapting the Tanganyika model to local conditions. Notwithstanding the uncompromising opposition of the Chief Commissioner, A.H.C. Walker-Leigh, to the institution of indirect rule or Native Administration in

4 See Maasole (2017) Ghana Journal of Development Studies, Volume 14, No2, October, 2017 pp.267-281.

5 PRAAD, Tamale, NRG/2/23, Report on the Northern Territories, $3^{\text {rd }}$ July, 1928. 
Northern Ghana, the principle of direct taxation as a means of raising revenue was accepted in the 1930 after his retirement.

With the change of Chief Commissioners, it became possible to put into operation the policy suggested by Sir Shenton Thomas. The District Commissioners were instructed to make careful enquiries into the history, constitutions, customs and customary law of the people in their districts with a view to the conferment of effective jurisdiction on the chiefs. They were also required to collate such information as existed on traditional forms of taxation before the advent of British rule in the area and which would pave the way for the re-imposition of direct taxation. This system of direct taxation would serve as the principal means of providing the Native Administrations with the funds required for the payment of salaries to their employees and for the provision of such urgent needs of the people under their control, such needs as water supplies, dispensaries, clinics and schools.

The District Commissioners immediately began to work towards the achievement of the goals set before them ${ }^{6}$. As on the previous occasions, the proposals to reintroduce direct taxation raised certain problems. These concerned the form, level and purpose of the tax, its handling and method of payment and who was to pay the tax.

In the discussions on the tax some of these problems were resolved without much difficulty; others had to be tackled with greater caution. The Administrative Officers recognised that whatever kind of tax was levied, the rate should be low in view of the fact that most of the people in Northern Ghana were not financially well off. They were also agreed that payment should be in cash and not in kind. There was no doubt too in their minds as to how the tax should be handled. Since taxation was to be closely bound up with Native Administrations, the chiefs and these institutions would collect the tax and use it for the development of their respective areas under the supervision of the District Commissioners 7 . With regard to the form of the tax, the choice lay between a flat rate poll tax and a graduated income tax. The latter was rejected because it was felt that the income of the inhabitants of the area who were largely rural farmers could not be properly assessed. The economic structure in the family systems whereby sons tended to farm with their fathers made it difficult to assess their own individual incomes ${ }^{8}$. The choice therefore narrowed down to a kind of poll tax payable by all adult males. It was not foreseen that there

6 PRAAD, Tamale, NRG/8/2 Jones to Colonial Secretary, Memorandum on Direct Taxation in the Northern Territories, $5^{\text {th }}$ November 1934, p. 5 .

7 Ibid.pp. 24-30.

8 Staniland, M. (1975). The Lions of Dagbon: Political Change in Northern Ghana, Cambridge, Cambridge University Press, pp. $92-98$. 
would be objections to the tax on the part of individuals or groups of persons. The District Commissioners simply assumed that once the tax was sanctioned by the chiefs, every adult male, whether indigenous in the area or not would readily pay it. However, people who hailed from Southern Ghana who were living in Northern Ghana were protesting and refused to pay the tax on the grounds that they were not subject to the Native Administrations that were being established. The Chief Commissioner, William John Anthrew Jones had to use a certain amount of pressure to oblige them to submit to the payment of the tax.

The decision to levy a poll tax on each male adult raised a much more fundamental problem: the basis for taxation. Whatever its form or the rate, the administration was nervous about the tax. Memories of the Sierra Leone rebellion of 1898 died hard among the Administrative Officers and they were anxious to avoid a similar insurrection in Northern Ghana9. Also the Aba Riots in Nigeria were very much economic in origin: a protest as much against the imposition of taxes at a time of economic hardship as against the system of local administration ${ }^{10}$. Sir Arnold Hodson who had recently arrived in Accra to succeed Sir Shenton Thomas as Governor, deprecated hastening direct taxation and said he would not recommend anything like that to the Secretary of State until he had been in the Gold Coast for considerable some time and had been able to study the question more carefully. Hodson opposed the introduction of taxation at any early date and wanted to hang up the scheme ${ }^{11}$.

The grounds of his objection were various and varying. One was the fear of disturbances in Northern Ghana which Government troops might have to quell. Another was the unfairness of taxing the inhabitants of Northern Ghana when it was not possible to tax similarly the Colony and Asante. Yet another was what he thought was the absence of formally educated chiefs to work with. However, he was prepared to recommend Jones' proposals to the Secretary of State on the condition that it should be introduced for an experimental period only, and secondly the tax was imposed in the name of the Native Authorities and not as a measure forced on the people from above ${ }^{12}$. A justification had therefore to be found for the tax in order to convince the people to accept it and to facilitate its easy collection. This led

9 Staniland, M., op. cit. p. 93.

10 Michael, C. (1968), West Africa under Colonial Rule, London, Hutchinson and Co. (Publishers) Ltd, p. 475 .

11 PRAAD, Accra, ADM56/1/229, Minutes on Sir Arnold Hodson's Despatch to the Secretary of State on Direct Taxation in the Northern Territories, $16^{\text {th }}$ April, 1935.

12 PRAAD, Tamale, NRG8/2/30, Commutation of Tribute. Colonial Secretary to Jones, expressing the Governor's fears of the tax and its effects on the people, $6^{\text {th }}$ May, 1936. 
to considerations of any traditional forms of taxation that existed under the chiefs before the imposition of British rule in Northern Ghana.

In 1928, Sir Shenton Thomas had anticipated this problem when he gave his approval in principle to the introduction of direct taxation in Northern Ghana. As a preliminary step to the adoption of a direct tax, he had requested to be furnished with accurate information on the following points:

what kind of dues were paid by the people in each District to their chiefs, the method of payment, their cash value or payment in the form of labour, whether all the ethnic groups paid such dues, and how these dues could be commuted into a $\operatorname{tax}^{13}$.

Between 1930 and 1934, the District Commissioners had already set to work to find a basis for the tax. Intensive enquires were made into the nature and extent of customary dues or tribute. It was during these years that intellectuals, such as Harold Arthur Blair, in Colonial Service exhibited their scholarly qualities in drawing up the traditional constitutions of states such as Dagbon, Mamprugu and Gonja, and recording their financial resources ${ }^{14}$. By 1934, much information had been collected from which the British Administration was able to identify three types of customary dues paid to chiefs.

The first were religious dues payable by every male adult who farmed on his own. At some intervals, particularly in a time of disaster, such dues were paid to the Tindanas (Earth Priests) either in cash or in kind for sacrifices to be offered to the ancestors or the Spirit of the Earth. In Dagbon, these dues were fairly regular, but a very small proportion of them actually reached the chiefs. In addition, farmers made offerings in thanksgiving to the Tindanas for a good harvest. As the offerings were of voluntary nature they could not be properly classified as customary dues or tribute. The Chief Commissioner was therefore against converting such dues to a tax. He said, "They formed too integral a part of the religious life of the people to permit of this being done" ${ }^{15}$

The second category of dues consisted of occasional presents made to the chiefs at festival times or in homage to new chiefs at the time of their installation. But as Staniland (1975) has pointed out, such gifts were obviously inappropriate for

13 PRAAD, Tamale, NRG8/2/30, Commutation of Tribute: Memorandum by the Chief Commissioner, W. J. A. Jones, dated $6^{\text {th }}$ November, 1934, pp. 1-2.

14 See for example, Duncan-Johnstone, A. C. and H. A. Blair, Enquiry into the Constitution and Organisation of the Dagbon Kingdom, 1931.

15 PRAAD, Tamale, NRG/8/2/30, Communication of Tribute, Memorandum by the Chief Commissioner, p.3. 
purposes of taxation and were therefore discounted when assessments of the cash value of the customary dues exacted by the chiefs were made ${ }^{16}$.

The third class of dues was what the Administration regarded as feudal dues. They were defined as, "Payments by the conquered to the conquerors or by the protected to the protectors"17. Such dues could be properly classified as tribute paid to the chiefs and would form the basis for the proposed poll tax.

In Dagbon, evidence was found to support this argument. The enquiries made by the District Commissioners disclosed the fact that prior to the European occupation of Northern Ghana, there existed in Dagbon,

A well-defined system of tribute from the people to their chiefs. A prescribed quantity of yams, corn and other food stuff was paid by the head of a compound to the local chief who retained his share and sent the remainder to the divisional chief. The latter, in his turn, took his portion and transmitted the residue to the Paramount Chiefs. In this way, the Dagomba recognised the right of their chiefs, as rulers on behalf of the community, to a share of the usufruct of the land. Furthermore, the chiefs were entitled to and received the free assistance of their people in the cultivation of their farms as well as in the building and maintenance of their houses ${ }^{18}$.

To the Administration, this was proof that in pre-colonial Dagbon, a tax structure did exist in the form of tribute and that under this system; a portion of the tribute was appropriated by each ruler, beginning from the lowest to the highest, the Ya $\mathrm{Na}$ or Paramount Chief. In addition, the subjects had to provide labour services in agriculture and house building ${ }^{19}$.

The value of the labour provided by each adult male was estimated at six pence per annum, and that of the compulsory tribute at two shillings. A tax of two shillings and six pence a year was therefore thought to represent a fair commutation of the customary dues ${ }^{20}$.

In Mamprugu, it was also found that the payment of tribute in labour and in kind was well established and general throughout the Kingdom. The Mamprusi also paid dues in money. A Village headman contributed annually to the maintenance

16 Staniland, M. (1975), The Lions of Dagbon, op. cit, p. 95.

17 PRAAD, Tamale, NRG/8/2/30, Commutation of Tribute: Memorandum by Chief Commissioner, p. 3.

18 Staniland, M. (1975), The Lions of Dagbon, op. cit, p. 35.

19 Information from Iddrisu Adam, A Dagomba Elder at Kumbungu, $16^{\text {th }}$ August, 2013.

20 18. PRAAD, Tamale, NRG/8/2/30. Commutation of Tribute: Memorandum by Chief Commissioner, p. 4. 
of his superior chief and arranged sums, varying between six pence and twelve shillings according to the number of people subject to his control. He levied a tax of three to six pence on each compound head, which he paid a portion to his chief and retained the remainder. The divisional chief took his share of the tribute and sent the remaining portion to the Nayiri or the Paramount Chief. Then there was a yearly contribution by each village or compound head towards the wages of court messengers. The chiefs were also entitled to, and demanded labour services on their farms and in the construction and maintenance of their houses ${ }^{21}$. Again, the Administration considered such dues and tribute as a proof of a well-defined traditional tax system since they were certainly a source of revenue to the local chiefs and the Paramount Chief, the Nayiri. The Administration then estimated the value of tribute paid in kind and in labour at between $2 \mathrm{~s} 6 \mathrm{~d}$ and $3 \mathrm{~s} 4 \mathrm{~d}$.

In Dagbon and Mamprugu, the British Administration found a basis and a moral justification for the imposition of a direct tax. The cash equivalent of the customary dues would form the basis on which the tax would be assessed. The payment of the customary dues provided the moral justification for the tax. What was not clearly established, however, was whether customary tribute constitutes a tax, and if it did, what traditional sanctions were imposed on those who refused or failed to pay it. A District Commissioner at Yendi, Charles Cockey, made investigations into this aspect of customary tribute in Dagbon. He found that no penalty was imposed on Dagombas who did not pay the tribute. On this basis, Cockey thought that the customary dues could not be regarded as amounting to a tax and this led him to conclude that there was never any real form of taxation in Dagbon ${ }^{22}$. Yet, in spite of his findings, the majority of the District Commissioners as well as the Chief Commissioner himself were eager to associate the new tax with the tribute paid to chiefs in pre-colonial times. By doing so, the tax would acquire some of the legitimacy attached to the customary dues and would therefore be more acceptable to the people than an arbitrary levy imposed on them by the government ${ }^{23}$.

However, the idea of presenting the tax as a commuted form of tribute ran into difficulties when applied to other areas in Northern Ghana. The problem was whether tribute had also been paid to Chiefs outside of Dagbon and Mamprugu, which would form a suitable and a justifiable basis for the commutation. According to Der, in Gonja, a large centralised state, the most important obligation imposed by the chiefs on the people before that state came under British rule was military service and not tribute in kind. This was done to aid them in the circulation of

\footnotetext{
21 Ibid.pp. 6-7.

22 Ibid.pp. 7.

23 Staniland, M. (1975). The Lions of Dagbon, op.cit., p. 95.
} 
succession to chiefly office, and which often involved inter-divisional conflicts, He maintains that with the advent of European rule this liability to military service ceased to exist and the Gonja no longer did military service to their chiefs. Der thought that it was difficult for the British Administration to commute a service, a service that no longer existed into an acceptable tax, and that there was evidence that the Gonja chiefs did not exact tribute of any kind ${ }^{24}$.

However, it has been found out that payment to Chiefs, in Gonja was equally elaborate. Village headmen paid tribute to clan chiefs, these in turn paid tribute to divisional chiefs who also paid the same to the Yagbunwura. For example, the Kpembewura had to pay tribute to the Yagbunwura on the occasion of Gonja national festivals ${ }^{25}$.

Baba D. Kondaayi testified to the traditional customs of the Kpandai area as follows:

All hunters who killed animals through hunting should bring the hinder (sic) legs to my late father. They had carried out this custom peacefully and all hunters who killed animals had been giving the hinder-legs (sic) to my late father during his reign. Secondly, when an elephant was killed my father used to get the tusk as custom demanded. No objections were raised to these customs ${ }^{26}$.

In Gonja, any dead animal found in the bush belonged to the village head. A tusk of an elephant found dead was sent to the chief and the hunter kept the other. The meat of one hind leg of any big game killed by a hunter such as an elephant, rhinoceros, roan, water buck, and buffalo was given to the Gonja Chief. The meat of one front leg of the animal was given to the village headman in whose K'damang (Tindana) area the game was killed as customary tribute. One tusk and one ear of an elephant, particularly those lying on the ground together with the meat of one thigh of the animal was sent to the chief. The sending or offer of the tusk and ear lying on the ground was significant. "It is an acceptance of the fact" as it has been explained, "that the land belongs to the chief. The ear of the elephant was used for covering the chiefs talking drums" ${ }^{27}$.The chief was not to be given the hind legs of small animals killed as these went to the village head. During funerals, one hind

24 Information gathered from Professor B. G. Der, University of Cape Coast, Department of History, $20^{\text {th }}$ March, 2013.

25 Information obtained from the Bambale-wura, a sub-divisional chief in the Kpembe Division of East Gonja, at Salaga $4^{\text {th }}$ June, 2013.

26 Al-Hadji Baba Kandaayi, Chairman, Alfai Local Council, Kpandai. Memorandum Notice of Enquiry to J. Dixon, 25-3-1955.

27 Report by Gonja Traditional Authority's Reply to the Justice and Peace Commission of the Catholic Church of Ghana on inter-Tribal Conflicts in Ghana, 1984. 
leg of the animal slaughtered by the chief mourner was given to the Gonja chief as tribute. The Gonja traditional version emphasised that this particular custom was observed by the Gonjas as well, and that there was no discrimination in the payment of tribute ${ }^{28}$.

Furthermore, it was considered that all rivers belonged to Gonja chiefs. Any stranger who fished in a river paid a customary tribute of fish to the Gonja chief every Friday. Chiefs or the village headman entered into contract with any fisherman who wanted to fish in large ponds owned by the former. When villagers fished communally in their ponds, which was an annual affair, a portion of each catch was given to the Gonja chief, and a sizable proportion was also given to the village headman ${ }^{29}$.

Equally, it was customary that during harvest, the people sent some of their harvested crops to the chief as a gift. This was done in order to obtain the chief's blessing for a better harvest during the next year. During the annual religiopolitical festivals, such as Damba, when many people came in from their villages for the celebration, the chief asked the people to help him with foodstuff with which to prepare food for the visitors. It was possible that some of the contributors would be among the visitors who would come to take part in the festival ${ }^{30}$. The Gonja have drawn attention to this passage in the Bible, in which Jesus said, "Render to Caesar, the things that are Caesar's, and to God, the things that are God's", as a justification for them to enjoy as landlords, the fruits of their land ${ }^{31}$. In the face of such overwhelming evidence of payment of customary tribute in Gonja, Der must have erred when he argued to the contrary.

Indeed, the Chief Commissioner, Jones, argued that Gonja Chiefs must have exacted tribute in kind from their people before the arrival of the British. The authority of the Yagbonwura (the Gonja king), he reasoned, was firmly established, generations before the coming of colonial rule. Like the Dagomba and the Mamprusi, the Gonja had a well-defined constitution as well as a clear conception of the powers exercisable by the Chiefs at the various levels. It was therefore unlikely, Jones thought, that the Yagbonwura and his subordinate Chiefs would not have used their authority to demand and enforce the payment of tribute in kind ${ }^{32}$. It was further argued that in Gonja the District Commissioners, as in any other traditional area, made consistent demands for free labour for the construction and maintenance of roads and station buildings. In addition, men were employed as carriers to

28 Ibid.

29 Ibid.

30 Ibid.

31 Ibid.

32 PRAAD, Tamale, NRG/8/2/30. Commutation of Tribute: Memorandum by the Chief Commissioner, p. 5 . 
convey goods from one administrative centre to another. The carriers, it is true, were given a small daily wage if they were employed outside their own Districts but for the most part they received no pay for the work they did. Jones felt therefore that such services amounted to a tribute in labour exacted by their "new chiefs", the District Commissioners. These forms of tribute introduced by the British could thus be taken into account in imposing a direct tax on adult males ${ }^{33}$. Thus the Gonja traditional accounts and the Chief Commissioner's argument when taken together could not be considered as speculative evidence as Der would have us believe. They formed the base for the imposition of a tax.

In the other uncentralised areas, the Reports stated quite definitely that the people paid no tribute either in kind or in labour to Chiefs even though they recognised their authority. From Wa, for instance, the District Commissioner, H. G. Ardron, reported that "no customary dues are paid to chiefs by any of the tribes ${ }^{34}$ ". Whatever work was done on chiefs' farms or in the construction of their houses before the arrival of the British was voluntary and was in no sense regarded as tribute either by the chiefs or by the people themselves. Yet the District Commissioners felt that labour exacted by them through the agency of the chiefs for the construction of roads and government buildings over the 34 years of British rule in these areas had taken on the character of customary dues and tribute. They could thus be justifiably commuted into a tax ${ }^{35}$.

Despite the evidence that there was never any form of direct taxation in some parts of Northern Ghana in pre-colonial times, the notion of presenting the tax as a commuted form of customary tribute appealed strongly to the British Administrative Officers. It was therefore decided to use the "tribute formula" as the basis for the tax. Administrators were all of the opinion that the time had come for the introduction of the tax and that any further delay would compromise the successful implementation of the scheme. Jones succinctly expressed their views and feelings in the following words: "We missed our chance in the Colony, we missed it in Ashanti. We will miss it in the Protectorate if the introduction of direct taxation is much delayed"36.

They felt that the chiefs in the North still retained a relatively large measure of real authority over their people in contrast to the chiefs in the Colony. They could therefore enforce measures that might be unpopular with their subjects as they

33 Ibid.

34 Ibid.

35 PRAAD, Tamale, NRG/8/2. Ardron to Chief Commissioner of the Northern Territories, 1934.

36 PRAAD, Tamale, NRG/8/2/30. Commutation of Tribute: Memorandum by Chief Commissioner, 1934, p. 9. 
did not exercise their power under the constant threat of fear of destoolment. The District Commissioners also expressed the fear that the people of Northern Ghana were making too rapid a progress, and that if an educated elite emerged before a system of direct taxation were introduced they would constitute a core of organised opposition to such a measure as was the case in the Colony ${ }^{37}$.

Convinced by these points of view, Hodson, the Governor changed his mind and endorsed the decision to begin the process of introducing the tax in the Protectorate. He, however, emphasised that the rate of the tax should be fixed in accordance with the individual's ability to pay $^{38}$. Consequently, assessments were made in the different Districts of the average adult's capacity to pay the tax without undue hardship. In the end, the rates agreed upon varied for each adult male from one shilling in the less developed areas to three shillings in parts of Gonja ${ }^{39}$. There was thus no uniform flat rate tax as some District Commissioners had advocated but the level was low enough to enable the average tax payer to pay it without much difficulty.

The Administrative Officers then intensified their propaganda campaign which they began as far back as 1930 on direct taxation. Every possible step and means were taken to make the object of direct taxation known to the people. Accordingly, the District Commissioners travelled within their Districts, holding meetings not only in the large towns but also in the villages, at which the people were told that the tax would be a commutation of the tribute in kind and labour which they paid to the Chiefs. It was also explained to them that the customary tribute was a far greater burden on them than the proposed tax would be abolished ${ }^{40}$. The campaign proved successful and by May, 1935 the District Commissioners were able to give an assurance that every person had had an opportunity to learn of the proposal to impose an annual tax and of the benefits that the individual would derive from it in terms of social services. Late that year, the Secretary of State's approval for the introduction of the tax reached Tamale but it was not until November, 1936 that direct taxation was introduced in the Protectorate.

37 Ibid. Memorandum on Direct Taxation, November, 1934, p. 47.

38 PRAAD, Tamale, NRG/8/2. Minutes to Hodson's Dispatch to the Secretary of State on Direct Taxation in the Northern Territories, 1935.

39 PRAAD, Tamale, NRG8/2/199. Memorandum from Governor Hodson of the Gold Coast to Secretary of State, $16^{\text {th }}$ April, 1935.

40 38. PRAAD, Tamale, NRG8/2. Chief Commissioner's Letter, Jones, to the Colonial Secretary, giving the proposed rates of the tax. 


\section{Direct Taxation Returns to Northern Ghana}

Unlike the earlier tax for which no administrative measures had been devised for its collection, elaborate machinery was set up to facilitate the collection of the new tax. A class of small but literate indigenous clerks was trained under the District Commissioners to handle the collection of the tax. In this connection, metal discs bearing the initials of the respective Native Administrations were imported from Britain to serve as receipts to the illiterate tax payer. More significantly, nominal rolls of taxable adult males in the entire villages in the Districts were compiled with the assistance of government and mission school boys. These nominal rolls enabled the Native Authorities to determine with some accuracy the amounts of tax to be collected in an area based on the assessments adopted in the various Districts ${ }^{41}$.

The method of collection employed was as follows: the Native Authority ascertained from the nominal roll the number of taxable males in a subordinate Native Authority area or a village. The subordinate native authority or sub-chiefs was then given discs receipts to the number of the taxable males. The sub-chief repeated this process to the headman or headmen if he had charge over several villages. The headman then issued the discs to the compound or household heads who in turn distributed them among those whose names were on the nominal roll. The Native Authority did not concern itself as to whether each individual paid the exact tax. All that it required was the amount equivalent to the value of the discs issued ${ }^{42}$.

At the village level, therefore, it was the headmen and the sub-chiefs who actually collected the tax and took it to the Native Authorities. If a headman or sub-chief was given one hundred discs in a District where the tax was assessed at one shilling per adult male, it meant he had to return 100 shillings or five pounds to the Native Authority. Where taxable members of a compound or household were absent at the time of the collection of the tax, the head of the compound paid the tax for all the absent members and then recovered it from them on their return home ${ }^{43}$.

An alternative method was for the Native Authority to call the headmen and subchiefs to a general meeting at which the period of collecting the tax was discussed. The receipt discs were then issued to them for distribution to the tax payers based on the nominal rolls of the previous financial year. Deaths of tax payers in the villages were reported to the Native Authorities and the names of the deceased removed from the nominal rolls. Then just before the harvest, that is, OctoberNovember, the chiefs, sub-chiefs and the District Commissioners toured the villages

\footnotetext{
41 Ibid.

42 PRAAD, Tamale, NRG8/3/23. Northern Territories Report for the year 1936/37, p. 10.

43 PRAAD, Tamale, NRG/8/2/23, Northern Territories Report for the year 1937/38, p. 20.
} 
and took a census of the population. During these tours, roll calls of the tax payers were made at the gatherings and the heads of household went to pay the tax, which they would have already collected from the members of their compounds, to the Treasurer of the Native Authority Treasury. The list of villages in a division was then checked by the District Commissioner against the amounts collected. It was also at these gatherings that boys of taxable age were selected and their names entered on the nominal rolls against subsequent financial years ${ }^{44}$.

The advantages of the latter method were that it enabled the Native Authorities to revise the nominal rolls every year and bring them up to date. The collection of the tax was effectively supervised as the District Commissioners were able to check the returns on the spot. This checked embezzlement of funds during the collection of the tax itself and ensured a fair dealing towards the people. The tax was also collected at opportune moment when the crops were ripe for harvesting. This fact alone enabled many tax payers to sell small portions of their farm produce and obtained the money to pay the tax without much hardship.

The yield of the tax in 1936 when it was first collected exceeded the expectations of the Administrative Officers in the Protectorate. It had been estimated that less than $£ 13,000$ would be collected in view of the inexperience of the chiefs in the work of tax collection. The aggregate sum collected, however, amounted to $£ 18,500^{45}$. In the financial year of 1937-38 the estimates were fixed at $£ 19,274$ but once again they were exceeded in every Native Authority as Table 1 shows:

44 Ibid.

45 PRAAD, Tamale, NRG8/2/30. Memorandum from E. W. Ellison, District Commissioner, Lawra to Jones, Chief Commissioner, $18^{\text {th }}$ February, 1937. 
Table 1: Estimated, actual and excess amounts of taxes collected in pound sterling for the 1937 - 38 financial year by various native authorities

\begin{tabular}{|l|l|l|l|}
\hline Native Authority & $\begin{array}{l}\text { Estimate 1937-1938 } \\
(\boldsymbol{(})\end{array}$ & $\begin{array}{l}\text { Amount Collected } \\
(\boldsymbol{(})\end{array}$ & $\begin{array}{l}\text { Excess Over Estimate } \\
(\boldsymbol{( \varepsilon )}\end{array}$ \\
\hline Builsa & 813 & 830 & 17 \\
Dagbon & 4,620 & 4,679 & 59 \\
Gonja & 1,532 & 1,585 & 53 \\
Kasena-Nankani & 1,434 & 1,437 & 3 \\
Krachi & 550 & 606 & 56 \\
Lawra & 1,020 & 1,050 & 30 \\
Mamprugu & 7,463 & 8245 & 782 \\
Prang & 250 & 251 & 1 \\
Tumu & 300 & 360 & 60 \\
Yeji & 92 & 94 & 2 \\
Wa & $\mathbf{1 , 2 0 0}$ & $\mathbf{1 , 3 1 6}$ & $\mathbf{1 1 6}$ \\
\hline TOTALS & $\mathbf{1 9 , 2 7 4}$ & $\mathbf{2 0 , 4 5 3}$ & $\mathbf{1 , 1 7 9}$ \\
\hline
\end{tabular}

Source: PRAAD, Tamale, NRG8/3/23, Northern Territories Report, 1937-38, p. 20

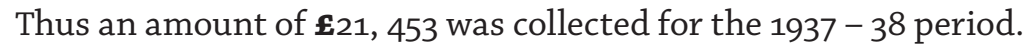

Some of the excesses were indeed negligible but from the point of view of the Administrative Officers what was significant was the acceptance of direct taxation by the people.

In an exhaustive report on the collection of the tax forwarded to the Colonial Office in London, Jones noted with pride and satisfaction at the fact that direct taxation had been imposed and collected without a hitch in Northern Ghana ${ }^{46}$. In other parts of West Africa, direct taxation by the colonial government in any form had encountered outright resistance and open rebellion. In Sierra Leone Governor Cardews Hut Tax had led to a serious uprising although it is now admitted that it was not the only cause of the rebellion ${ }^{47}$. In Nigeria, Lugard's attempts to introduce direct taxation in the South were followed by riots in Oyo towns such as lseyin and Abeokuta while in the French Colonies of Guinea and Upper Volta (now Burkina Faso) it was maintained at or by the use of force ${ }^{48}$.

46 Ibid. p. 21.

47 PRAAD, Tamale, NRG8/3/23. Northern Territories Report, 1937-38, pp. 20-21.

48 46. Denzer, La Ray and Crowder, M. "Bai Bureh and the Sierra Leone Hut Tax War of 1898" in Protest and Power in Black Africa, edited by Robert. I. Rotberg and Mazrui, A. Ali, Oxford, 1970, pp. 172-82. 
In Northern Ghana the situation was entirely different. Direct taxation was levied without any resistance from the people. The chiefs and their subjects accepted it without opposition and readily paid it. At its first and subsequent collections no disturbances whatever occurred. They only protest against it came from the Government Officials of Asante and Colony origin stationed in the North. They had objected to the payment of the tax on the grounds that they were not subject to the Native Authorities that were set up or established in the North and that they were not therefore liable to the $\operatorname{tax}^{49}$. But Jones ordered them to pay on the argument that all Africans resident in the Protectorate were bound to pay the tax ${ }^{50}$.

The smooth and easy collection of the tax in Northern Ghana was again in marked contrast to African response to taxation in a neighboring country such as Burkina Faso where the French Colonial administration used coercive and harsh methods for collecting the poll tax. Suret-Canale (1971) notes that imprisonment for nonpayment of tax was common and that men and women who failed to pay the tax in present day Benin were often arrested, lashed or flogged together. Such instances of violence against tax payers were never reported in Northern Ghana by the Administrative Officers ${ }^{51}$.

Three main reasons can be attributed to the contrast in Northern Ghana. First, the propaganda of the District Commissioners was extremely effective in convincing the chiefs and the people to accept the tax. The people in particular were easily persuaded to accept direct taxation in place of tribute and forced labour. They were told that the proceeds of the tax would be used to build schools, hospitals, dispensaries and dams to provide water for them during the dry season. The hopedfor provision of these social amenities from the tax went a long way to convince the people to accept taxation. Secondly, the chiefs were the direct beneficiaries of taxation. It enabled them to recover their lost control over their subjects. Hence they used all their influence to persuade their people in favour of the tax. In the third place, the low rate of the tax enabled most tax payers to meet it without difficulty.

Direct taxation was not, however, the only means of raising revenue on the part of the Native Authorities. Monies were obtained from other sources such as market,

49 Crowder, M. (1968). West Africa under Colonial Rule, London, p. 208 and pp. 185-86.

50 Ibid. p, 23. Ali Nakyea (2008:3). He must have erred terribly when he stated that, "Taxation was first introduced in Ghana, then the Gold Coast in 1943 by the British Colonial Government at the time when World War II was raging".

51 See for instance PRAAD, Tamale, ADM1/34. Reports on Native Treasuries, Lawra District, 1935-1945; Native Treasuries, Tumu, 1935-1945; and District Taxation: Kasena-Nankani Native Administration Area. 
lorry park and slaughter house fees, pito licenses, whether sold in the markets or in the homes, tolls in respect of the use of public ferries, court fees and fines, rents, caravanserai and cattle kraal fees ${ }^{52}$. The amounts derived from these sources of revenue were small and did not need any elaborate measures for their collection. A Native Authority clerk or its representative accompanied by a Native Administration policeman visited the markets and villages to collect the taxes and turned them over to the Native Authority Treasuries.

\section{Post War Developments}

Between 1940 and 1950, direct taxation remained the main source of revenue for the Native Administrations but its nature and method of collection underwent little change. Certain developments, however, took place in the post war years which contributed to a more efficient collection and an expansion of revenue.

During the war years, some of the Native Authorities lost revenue owing to the recruitment of taxable or tax paying male adults into the army. They were, therefore, forced to raise the rates of the tax in order to make up for the losses ${ }^{53}$. These increases were the only modifications in the direct tax in the various Native Authorities, for, women and children continued to be exempted from it.

When the increases proved inadequate because they were in themselves low, the Gold Coast Government came to the assistance of the Native Authorities by providing them supplementary grants. At first the Government paid two shillings for every recruit to compensate the Native Authorities ${ }^{54}$.By 1946, the compensation had been turned into annual grants-in-aid on a "pound for pound" basis. If a Native Authority collected $£ 20,000$ in taxes it received a grant of another $£ 20,000$ from the Central Government for that year.

The institution of grants - in - aid in the post war years acted as a great spur to increase amounts collected by the Native Authorities affected their own revenues. Each Native Authority collected as much revenue as possible in order to obtain a bigger grant from the Government. Thus between 1940 and 1950, there was considerable expansion in the finances of the Native Authorities. In the financial year 1942/43, the Native Authorities collected $£ 68$,ooo in revenue as against the $£ 18,500$ in $1936 / 37^{55}$. In $1944 / 45$, the total revenue in the Native Treasuries was

\footnotetext{
52 PRAAD, Tamale, NRG8/2, Memorandum on Direct Taxation in the NTS by Jones, p. 13-14.

53 Ibid

54 PRAAD, Tamale, NRG8/2/30, H. W. Amherst District Commissioner, Lawra to Chief Commissioner, $26^{\text {th }}$ October, 1940.

55 Ibid. Jones to Amherst, $4^{\text {th }}$ November, 1940.
} 
$£ 86,000$ £98,00o in $1945 / 46$ and $£ 121,025$ in $1948 / 49^{56}$. These amounts did not include the sums granted by the Central Government and represented considerable increases in tax collection.

Other developments were the institution of a general audit system and the establishment of Finance Committees in connection with the administration of the taxes. In 1937 the Chief Commissioner had an auditor sent up from Accra to audit the accounts of the Native Treasuries. This practice became a permanent feature in the control of expenditure in the Native Administrations during and after the war years. Every year an auditor went up from Accra to audit the accounts of all the Native Authorities and make suggestions for improvement in the system ${ }^{57}$. After 1945 too, Finance Committees consisting of both the chiefs and their subjects were set up to further supervise the estimates and accounts of the Native Authorities. The Committees met regularly to scrutinise the accounts of their respective Native Authorities, drew attention to any unauthorised expenditure and assisted in the preparation of the Annual Estimates and Expenditure ${ }^{58}$. Both these administrative measures helped the Native Authorities to build up efficient treasuries and expenditures were rigidly controlled. The latter measure in particular stimulated popular interest in determining how best the proceeds of the taxes were spent since the meetings of the Committees were held in the open to enable the public to attend and participate in the discussions.

\section{Expenditure}

All taxes collected were utilised on the provision of schools, dispensaries, public buildings, improved markets, water supplies, sanitation and the payment of salaries to the chiefs and the Native Administrations employees. Education took a greater share of the Native Administrations' revenue. Out of 77 schools that existed in Northern Ghana by 1950, 64 were Native Authority Schools. Many of these schools were built between 1936 and 1950 and they show the considerable attention that the Native Authorities spent a total sum of $£ 4,680$ on education ${ }^{59}$. In 1945/46 recurrent expenditure was £11,220, £30,166 in 1948/49 and for the financial year of 1949/50, this was estimated at $£ 39,822$. For the same year, the estimated capital expenditure on education was $£ 40,419^{6 \circ}$.This made a total of $£ 80,241$ and represented nearly one quarter of the total estimated expenditure of $£ 331,523$. These amounts included

\footnotetext{
56 PRAAD, Accra, ADM56/1/229. Annual Reports on the Gold Coast, 1946, p. 49.

57 PRAAD, Accra, ADM56/1/446. Annual Report on the Gold Coast, Part iv, the War Years, p. 127.

58 Ibid. for 1944-46 and Annual Report on the Gold Coast for 1949.

59 PRAAD, Tamale, NRG8/3/49, C. V. E Graves. Audit Reports on Tumu NAT, 1942-44.

6o PRAAD, Accra, ADM56/1/139, Annual Report on the Gold Coast, 1947, p. 23.
} 
salaries spent on teachers and other staff, scholarships to pupils proceeding to the Training College, school meals, repairs to buildings, equipment, clothing, books, stationery and furniture ${ }^{61}$.

On health services in the form of dispensaries and dressing centres, the expenditure in $1945 / 46$ was $£ 9,833$. In the fiscal year of $1948 / 49$ it was $£ 20,962^{62}$. Similarly, expenditure on water supplies in the form of dams and wells rose from $£ 3,943$ in $1945-46$ to $£ 13,358$ in $1948-49$. For the 1949-50 financial year, this was estimated at $£ 17,238^{63}$. The Native Authorities also gave increasing attention to agriculture, animal health and forestry services.

In comparison with the figures of revenue and expenditure of the richer areas to the South such as Asante and the Colony, these amounts were trivial and seem very small. In the Northern Territories then, they were huge sums. The area had no export trade of any appreciable dimension and no industry as well. The only resource of the people was the land and money earned outside the area. Thus the comparatively few items of revenue had to be most carefully collected and no less carefully and wisely spent to ensure any reasonable degree of development in the area.

\section{Social Effects of Taxation}

There is remarkably little evidence of corrupt practices in the handling and expenditure of Native Administration revenue. The Audit Reports of the various Native Authority Treasuries show few instances of the misappropriation of Native Administration funds ${ }^{64}$. The Chiefs were paid monthly salaries and tended to disengage them from the handling of funds. In any case, the District Commissioners kept a strict control over the accounts of the Native Authority Treasuries, and were therefore able to check embezzlement. Another notable fact about tax collection in Northern Ghana was that it did not disrupt social and traditional life. Administrative Officers, including one Governor, Sir Shenton Thomas, had expressed the fear that direct taxation might lead to emigration if it were imposed only on the Protectorate. Governor Thomas had even gone so far as to suggest that measures should be devised to check such emigration from the Districts in the event of its occurrence ${ }^{65}$. Fortunately for the Administration, this

\footnotetext{
61 PRAAD, Tamale, ADM56/3/49. The Expenditure of the Native Administration from 1937/38 to 1943/44.

62 Packham, E.S. "Notes on the Development of the Native Authorities in Northern Territories of the Gold Coast" in Journal of African Administration, Vol.11, No.2, April, 1950, p. 28.

63 Ibid.

64 Ibid.

65 Ibid.
} 
did not happen. As noted, the tax, being low, could be paid without much hardship. District Commissioners reported no instances of migration or immigration in their Districts. The annual exodus of migrant labourers to the mines and cocoa farms in the South was already a well-established pattern of life among people of Northern origin before the imposition of the tax in 1936, the culture of migration down South was not therefore a direct consequence of direct taxation in the North ${ }^{66}$. The primary aim of migrant labourers was to earn money and invest it in clothes, cloths, sandals, shoes, hats, cutlasses and imported hoes if they stayed in the South over a year or two, the main objective was to make sufficient money to purchase a bicycle and return home ${ }^{67}$. Whatever savings were taken home by the young migrant labourer were handed over to his father or the head of the household who retained a portion and invested it in animal wealth; the rest was given back to him to spend it the way he liked. In most cases, the taken back home was often expended before the next tax collection and was not necessarily used to pay the $\operatorname{tax}^{68}$. Thus tax collection did not create a situation, as had been the case in other colonies, whereby the men left their homes in order to earn the money to pay it. Most migrant labourers left for the South after harvest, they were thus usually at home at the time the tax was collected. The majority of them therefore normally paid the tax before they went down South in search of employment. Indeed, during the hey-days of the Native Administration that is, 1936-1948, their records show little evidence of tax defaulters ${ }^{69}$.

Direct taxation in Northern Ghana was also less unpopular and less burdensome than in the French Colonies such as it was in Senegal and present day Benin. Women were exempted from it. A man who had several wives and daughters of taxable age did not have to find money to pay their part of the tax. This alone lightened the burden of taxation even if the rate had been higher. Men were not compelled to divorce their wives, nor were families reduced to selling their property in order to obtain funds to pay the tax. It did not also delay marriages in the area because the young men wished to evade the consequences of taxation by remaining unmarried. Thus taxation in Northern Ghana did not affect traditional morality by encouraging illicit unions between young men and women as was the case in Malawi ${ }^{70}$.

66 PRAAD, Tamale, NRG8/3/48. The Audit Reports of the Native Authority Treasuries.

67 PRAAD, Tamale, NRG8/2. Minutes by Sir Shenton Thomas on Direct Taxation in the Northern Territories, dated $21^{\text {st }}$ February, 1934 .

68 In 1927/28, 55, 562 migrant labourers went down South from the North. See PRAAD, Tamale, NRG8/2/30 and Annual Report on the Northern Territories for that period, p. 13.

69 PRAAD, Accra, ADM56/1/78. "Report on Labour Conditions" by Capt. J.R. Dickinson, Chief Inspector of Labour in the Gold Coast, June, 1939, pp. 4-8.

70 Ibid. p. 32. 


\section{CONCLUSION}

Taxation and tax collection in Northern Ghana therefore differed in certain notable features from those in force in other African colonies. The response of the inhabitants in Northern Ghana to direct taxation was substantially different from that of their neighbours to the South and other African peoples. It met with no resistance and was readily paid by the people. The reasons for this may be found in the propaganda of the District Commissioners which proved quite effective in convincing the people of its necessity and utility. The influence of the chiefs was also instrumental in persuading the people to accept taxation. The level of the tax itself was fairly low in comparison to what obtained in other African colonies and remained so over a period of years so that most tax payers could afford to pay it without undue hardship. Moreover, women were excluded from it and this exemption further reduced the burden of the tax.

The method of collecting the tax was such that it eliminated abuses in the system. Instead of leaving the process of collection entirely to either the Administrative Officers or to the Native Authorities, both parties participated in it with the one acting as a check on the other. The use of nominal rolls and disc receipts prevented the headmen and chiefs from inflating the lists of tax payers while the presence of the District Commissioners checked them from extorting money from their subjects. Once the people were assured that the proceeds of the tax would not go to augment the wealth of chiefs and that they would be used to provide social services such as education water supplies and health facilities, they willingly paid the tax. For not many cases of evasions and defaulters were usually reported at the time of collecting the tax. These checks and balances went a long way to rendering direct taxation and other forms of taxation in Northern Ghana less popular than they were in other parts of Africa. Tax collection in Northern Ghana was therefore one of the most successful administrative policies implemented by the British. Real development in terms of the provision of social services began with the reintroduction of direct taxation under the Native Administration system in the area.

Be that as it may, an historical study of this nature engenders knowledge creation for its own sake. It is intended to carry the study of tax collection into post - colonial Northern Ghana. In so doing, opportunity would avail itself to an examination of the extent to which British colonial tax collection policy was relevant or otherwise. 


\section{References}

Ali-Nakyea, A. (2008). Taxation in Ghana: Principles, practice and planning. $2^{\text {nd }}$ Edition. Accra: Black Mask Limited.

Crowder, M. (1968). West Africa under colonial rule. London: Hutchinson and Company (Publishers) Ltd.

Denzer, L.R. and Crowder, M. (1970). 'Bai Bureh and the Sierra Leone Hut Tax of 1898': In Roberg. I.R. and Ali A. Mazuri Protest and power in black Africa, Oxford: Oxford University Press, pp $172-182$.

Ekeh. P.P. (1994). The public realm and public finance in Africa: In Himmelstrand, U., Kinyanjui, K., and Mburugu, E. (eds) African Perspectives on development. Controversies, dilemmas and openings. New York: James Currey Ltd.

Lugard, F.D. (1965). The dual mandate in British Tropical Africa ( $5^{\text {th }}$ edition), London: Frank Cass.

Staniland, M. (1975). The lions of Dagbon: Political change in Northern Ghana. Cambridge: Cambridge University Press.

Nsoh-Ambala, R. (2008). A reference book for taxation in Ghana. Graphic Packaging Ltd.

Packham, E.S. (1950). Notes on the development of the native authorities in the northern territories of the Gold Coast. Journal of African Administration. Vol. 11. No. 2. $\operatorname{Pp} 167-181$

McCoy R.F. (1988). Great Things Happen: A Personal memoir of the first Christian missionary among the Dagaabas and Sissalas of Northern Ghana, Montreal: Society of Missionaries of Africa.

Rotberg. I.R. (1967). The Rise of Nationalism in Central Africa: The Making of Malawi and Zambia 1873-1964. Harvard: Harvard University Press.

Suret-Canale, J. (1971). French Colonialism in Tropical Africa 1900 - 1945, London: c. Hurst. 